\title{
Cancer-associated retinopathy
}

INSERM

\section{Source}

INSERM. (1999). Orphanet: an online rare disease and orphan drug data base. Cancerassociated retinopathy. ORPHA:71505

Cancer associated retinopathy (CAR) is a paraneoplastic disease of the eye associated with the presence of extraocular malignancy and circulating autoantibodies against retinal proteins. 